\title{
Displacement of water masses and remineralization rates off the Iberian Peninsula by nutrient anomalies
}

\author{
by Fiz F. Perez ${ }^{1}$, C. Mouriño ${ }^{1}$, F. Fraga ${ }^{1}$ and Aida F. Rios ${ }^{1}$
}

\begin{abstract}
Temperature, salinity, oxygen, nutrients and $\mathrm{CO}_{2}$ data obtained in the areas west and north of the Iberian Peninsula have been analyzed. We assume that the composite parameters such as Broecker's "NO" and "PO" and our own "CAO" and "SiO" are conservative for our water mass analysis. We demonstrate that the observations can be well represented by mixing between five end-members and estimate the relative proportions of these end-members in waters between $40 \mathrm{~N}$ and $47 \mathrm{~N}$. Furthermore, based upon the differences between the observed and computed concentrations of oxygen and nutrients, the approximate rates of oxygen utilization and nutrient production in each water mass are estimated. The type-values of the "NO," "PO" and "CO" parameters are used to compare the data obtained here with those recorded in other areas.
\end{abstract}

\section{Introduction}

The thermohaline characteristics of the water masses surrounding the Iberian Peninsula have been widely studied. Along the north and west coast, two different water masses of North Atlantic Central Water (NACW) (100-400 m) have been described (Fraga, 1981; Fraga et al., 1982). These water masses form a quasipermanent subsurface front close to Cape Finisterre that reinforces the upwelling. Recently, Ríos et al. (1992) characterized the origin of both North Atlantic Central Water masses, taking into account the descriptions by Harvey (1982) and Pollard and Pu (1985). These authors used the denomination ENAW (Eastern North Atlantic Central Water) for the NACW situated northeast of the subtropical gyre, to the east of the Azores. In this paper, NACW of subpolar origin (Harvey, 1982) is symbolized by ENAW and represents the water bodies situated to the north of Cape Finisterre (Fraga et al., 1982; Ríos et al., 1992), and by ENAW the NACW of subtropical origin (Fiuza, 1984; McCartney and Talley, 1982; Pollard and Pu, 1985) generally situated to the south of Cape Finisterre.

Mediterranean Water (MW) is characterized by a strong salinity maximum that spreads north through this area close to the continental slope of the Iberian Peninsula (Lacombe and Tchernia, 1960; Parrilla and Moron, 1971; Madelain, 1972). 
Recently Ríos et al. (1992) described the existence of a strong salinity maximum off Cape Finisterre, showing the important persistence of MW along the PortugueseGalician continental slope. The formation and spreading of meddies (Käse et al., 1989) northward give rise to the strong salinity maxima distant from their formation zone off Cape Finisterre. To the north and east of this Cape, an important frontal zone between ENAW $\mathrm{p}_{\mathrm{p}}$ and MW exists where the influence of MW decreases rapidly (Harvey, 1982; Ríos et al., 1992).

With regard to nutrient distributions in this area, most studies have been concerned with the coastal upwelling, and there are only a few exhaustive papers about the nutrient distribution as a function of the water masses present in this area (Coste et al., 1986). In the Bay of Biscay, Tréguer et al. (1979) observed linear correlations between the nutrients (nitrate and phosphate) and salinity, and distinguished two bodies of NACW of different origins (subtropical and subpolar) with salinities greater and less than 35.65. This value will be used here to distinguish between ENAW $_{\mathrm{p}}(S<35.6$; Harvey, 1982) and ENAW $(S>35.7$; Pollard and Pu, 1985).

In the Bay of Cádiz, Ambar et al. (1976) and Howe et al. (1974) described the nutrient distributions as a function of the mixing processes due to the formation and spread of the Mediterranean outflow along two separate sections.

Nutrient variability in the mixing of water masses has been studied in other Atlantic zones by other authors (Minas et al., 1982; Tomczak, 1981a; Fraga et al., 1985a). The analysis of triangular mixing of nutrients allows us to better describe the mixing processes, and, by comparing the deviations with a model, it is possible to find regions where the remineralization of organic matter (ROM) is relatively high (Tomczak, 1981b).

The aim of this paper is to estimate the relative aging of the different water masses surrounding the Iberian Peninsula, followed by changes of nutrients, oxygen and total $\mathrm{CO}_{2}$ due to $\mathrm{ROM}$, and to relate this aging to the mixing and displacement of water masses obtained from the thermohaline distribution. Through the mixing triangle analysis, the thermohaline variability is removed from the distribution of nutrients, oxygen and total $\mathrm{CO}_{2}$, and only the nutrient variability due to remineralization remains. This also allows us to chemically characterize the water masses off the Iberian Peninsula, and to compare them with data obtained within and beyond this area, using the Broecker parameters (Broecker, 1974).

\section{Material and methods}

The data used was taken on four oceanographic expeditions of the R/V Garcia del $C i d$ in different months of the year. The Galicia-V expedition was made in November 1982; Galicia-VI, in December 1983; Galicia-VII, in February 1984; and Galicia-VIII in July of 1984. The positions of all stations are shown in Figure 1. The data for temperature, salinity, oxygen and nutrients from the four oceanographic cruises and the methods used can be found in Mouriño et al. (1984, 1985), Pćrcz et al. (1985) and Fraga et al. (1985b). These data allow us to carry out an analysis of the average levels 


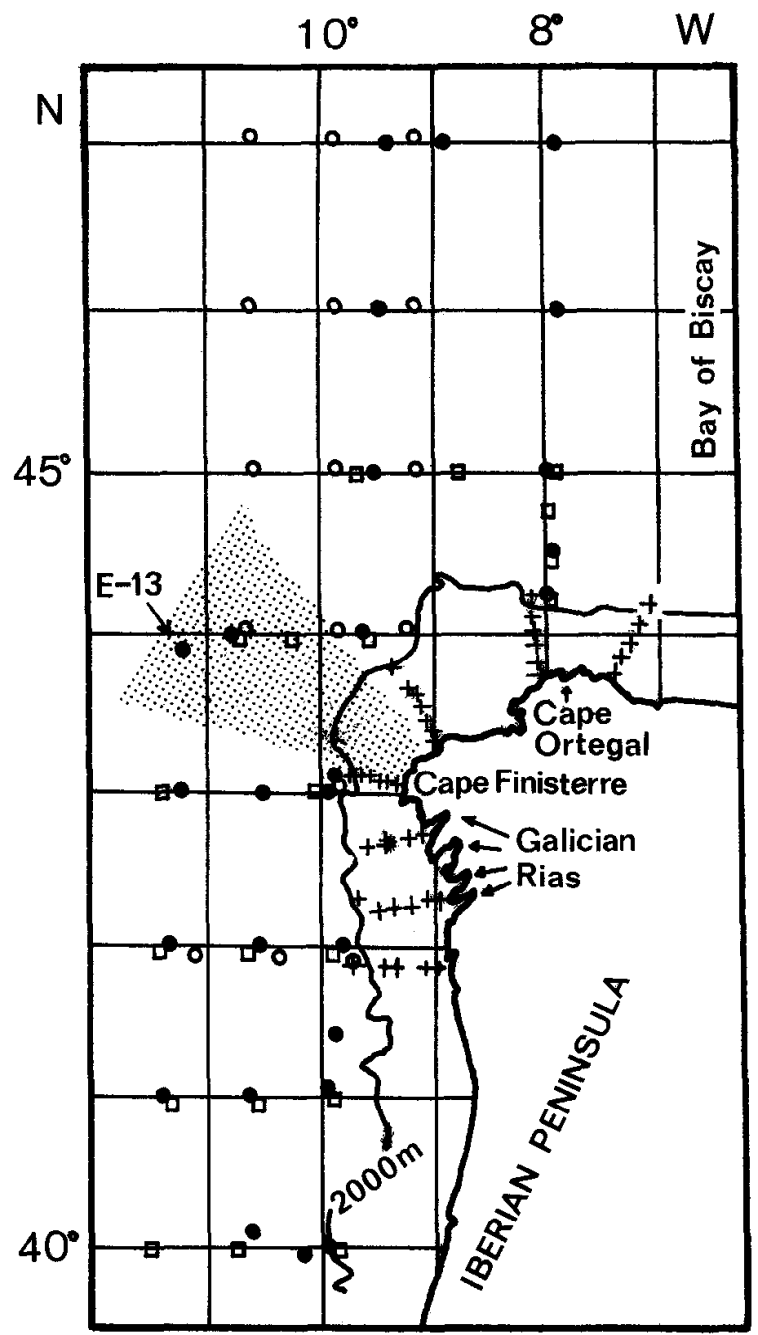

Figure 1. Positions of stations in the cruises Galicia V (Nov-82; open squares), Galicia VI (Dec-83; open circles), Galicia VII (Feb-84; dark circles) and Galicia VIII (Jul-84; crosses). The subsurface frontal zone (shadow) near Cape Finisterre is shown.

of nutrient, oxygen and total organic carbon of the water masses present in this area from the surface to $3000 \mathrm{~m}$. The seasonal variability of ENAW will be the aim of further papers.

\section{Previous work and theory}

a. ENAW displacement. Fraga et al. (1982) described the presence of a frontal zone situated to the northwest of the Iberian Peninsula, close to Cape Finisterre in which two water bodies of ENAW of different origin are found (Ríos et al., 1992). Fraga et 


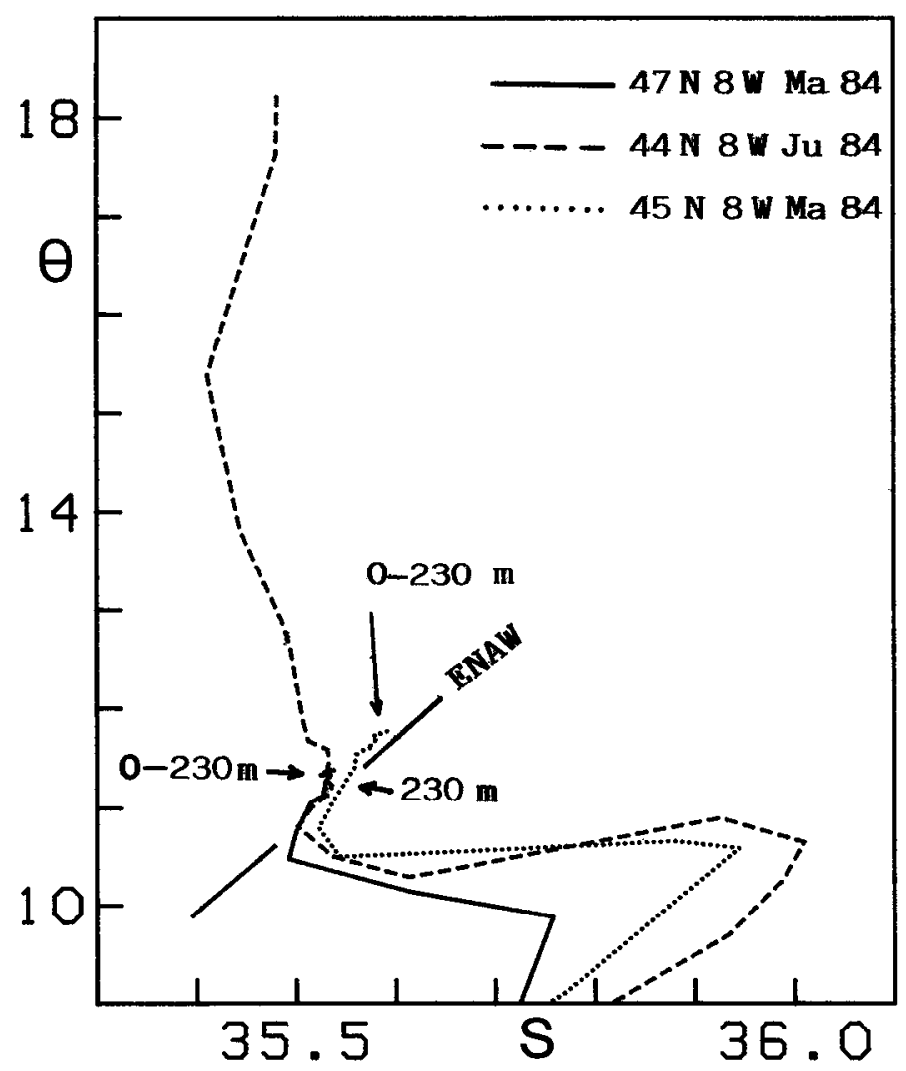

Figure 2. $\Theta-S$ diagrams to the north (a) and the south (b) of the frontal zone (Cape Finisterrre). The ENAW line is drawn according to Fiuza (1984).

al. (1982) suggested that the ENAW, and ENAW originate around $40 \mathrm{~N}$ and $47 \mathrm{~N}$ respectively. In Figure 2a the potential temperature-salinity $(\Theta-S)$ diagrams obtained to the north of Finisterre at the end of winter and in summer are shown. The agreement in the segments of ENAW between the $\Theta-S$ diagram obtained in March 1984 at $47 \mathrm{~N}$, and those obtained in July 1984 at $44 \mathrm{~N}$ close to the north coast of Galicia, supports the hypothesis of the displacement of ENAW $_{p}$ from north to south. On the other hand, Figure $2 b$ shows the $\Theta-S$ diagrams obtained to the south of the frontal zone in the same periods. The concordance between the $\Theta-S$ signatures in sections corresponding to ENAW of February-84 at $41 \mathrm{~N}$ and July-84 at $42 \mathrm{~N}$ supports the hypothesis that the ENAW, flows from south to north (Fraga et al., 1982).

The advection of ENAW $_{t}$ to Cape Finisterre has been described recently by several authors. At the end of autumn, Frouin et al. (1990) found a salty core flowing to the north along the Portuguese coast. Pollard and Pu (1985) also described the ventilation and advection eastward of a salty edge of ENAW from the Azores area. 


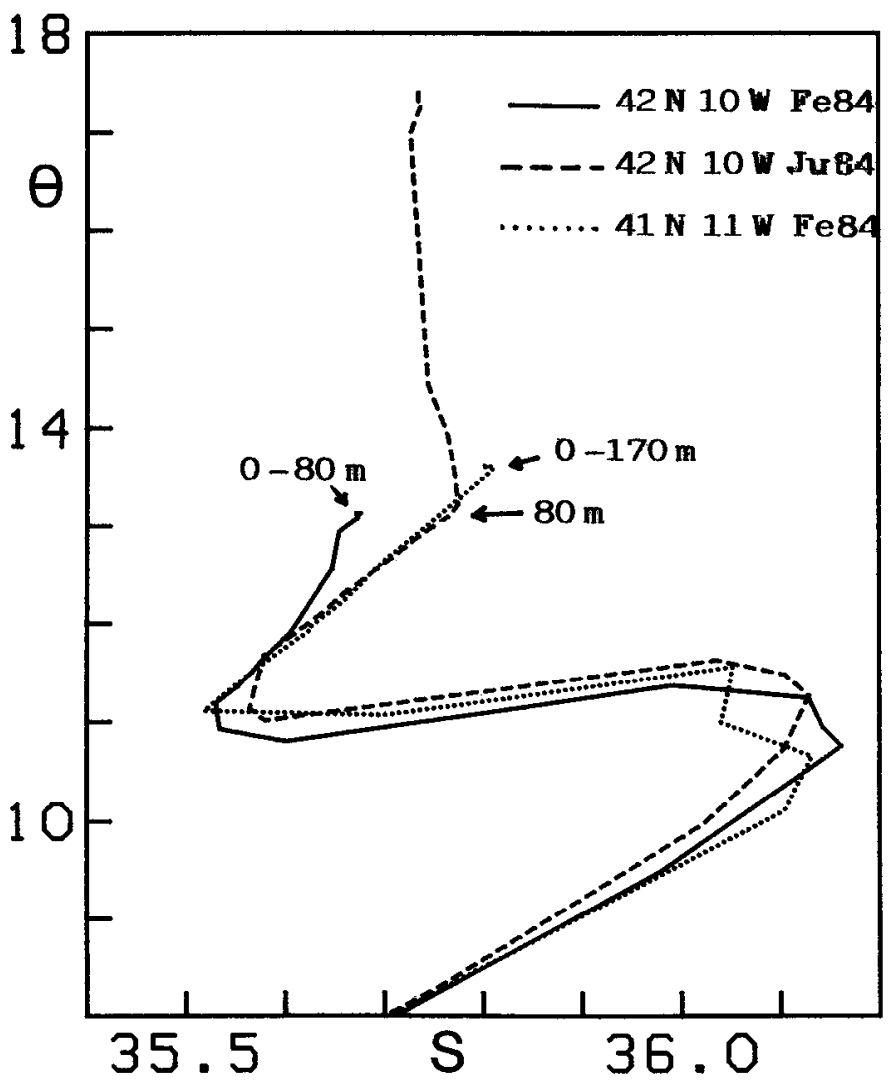

Figure 2. (Continued)

We hypothesize that these two ENAW masses are subjected to different ventilation rates or ROM, and thus contain different nutrient levels. So, these two water masses will be considered separately.

Due to the displacements of ENAW ${ }_{p}$ and $\mathrm{ENAW}_{\mathrm{t}}$ to Cape Finisterre from their formation areas, the thermohaline variability of ENAW found in summer (GaliciaVIII cruise, Fig. 1) is similar to that found during other cruises (Galicia-V, Galicia-VI and Galicia-VII) carried out in a vast area, in winter (Fig. 1).

b. Mixing model. The $\Theta-S$ diagram with the data from all stations is shown in Figure 3 . The triangles show the three levels of subsurface mixing and the values of their vertices are given in Table 1. The layout of these triangles represents, in a general way, the mixing profile of the water bodies detected in the northeast Atlantic.

The points representing the surface layer are situated above the ENAW and are not taken into account in the analysis. The thermohaline distribution of ENAW coincides with that given by Sverdrup et al. (1942). 'The water types symbolized by $W_{t}$ 


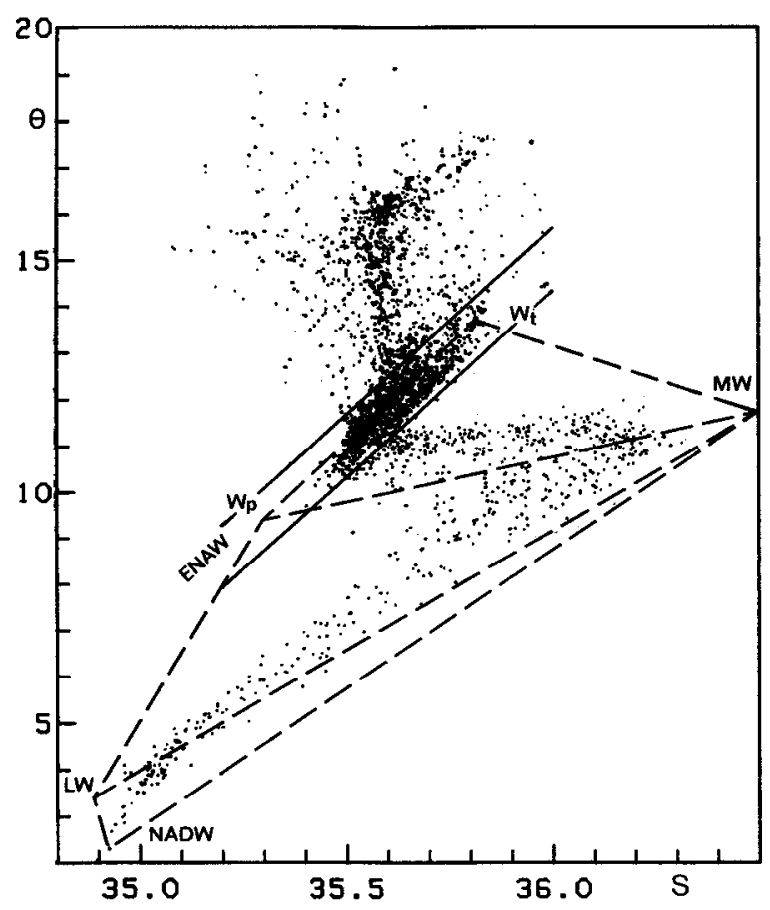

Figure 3. $\Theta-S$ diagrams for all stations shown in Figure 1. The three triangles and five water types used in the mixing model are shown.

and $W_{p}$ in Figure 3 represent the ENAW ${ }_{\mathrm{t}}$ and $\mathrm{ENAW}_{\mathrm{p}}$ respectively. To choose both points, we have taken into account:

(i) The salinity maximum of ENAW $\mathrm{W}_{\mathrm{t}}$ in the working area whenever it is not affected by mixing with surface water.

(ii) The slope of $W_{t}-W_{p}$ segment is the same as that given by Sverdup et al. (1942).

(iii) The maximum of MW in each profile (close to the salinity maximum situated at 1000 to $1200 \mathrm{~m}$ ) must separate the two mixing triangles $W_{t}-W_{p}-\mathrm{MW}$ and $W_{p}-\mathrm{MW}-\mathrm{LW}$. The MW type has been defined taking into account the thermohaline characteristics given by Wüst and Defant (1936) close to Cape St. Vicente (Table 1). The segment $W_{p}-\mathrm{MW}$ has been obtained from the linear regression of all the maxima of $\mathrm{MW}$ obtained in each profile.

The point $W_{p}$ obtained here to respresent the $\mathrm{ENAW}_{\mathrm{p}}$ is very close to the inflexion point of the $\Theta-S$ curve suggested by Harvey (1982, Fig. 5) for ENAW. The line that links this point with LW separates the representative points of waters with MW influence from those that are partly mixed with of SAIW (Subarctic Intermediate Water). 


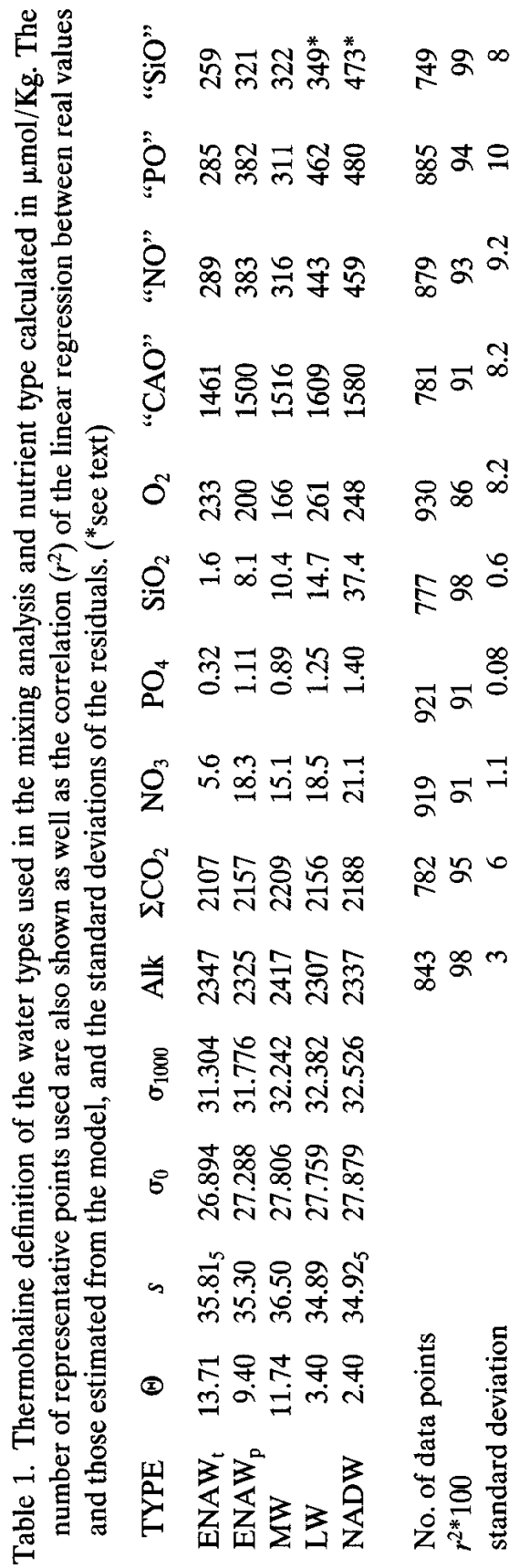


The mixing triangle $\left(W_{t}-W_{p}-\mathrm{MW}\right)$ shows the mixing processes of subsurface waters above 1000-1100 m. in which the different types of ENAW and MW are involved. Below this level the mixing between MW and LW (Labrador Water) is prevalent which is included in the mixing triangle $W_{p}-\mathrm{MW}-\mathrm{LW}$. To define the $\mathrm{LW}$ type, the thermohaline characteristics given by Talley and McCartney (1982) when the LW crosses the Mid Atlantic Ridge, are used (Table 1).

The North Atlantic Deep Water (NADW) is located below $2000 \mathrm{~m}$ (Harvey, 1982). We study the mixing processes through the MW-LW-NADW triangle. To define the NADW type, the thermohaline characteristics given by Worthington and Wright (1970) have been taken; this value represents the maximum volume found in the European basin. Summarizing, the mixing processes of the water masses present in the working area will be described from the three mixing triangles with five water types: ENAW, ENAW $_{\mathrm{p}}, \mathrm{MW}, \mathrm{LW}$ and NADW (Table 1).

Using salinity and potential temperature as conservative parameters in a three water type mixing triangle, the proportions of the three types $\left(M_{i 1}, M_{i 2}, M_{i 3}\right)$, for a sample $i$ with a given salinity and temperature $(S, \Theta)$, can be obtained by the following set of equations:

$$
\begin{array}{r}
M_{i 1}+M_{i 2}+M_{i 3}=1 \\
M_{i 1} \cdot S_{1}+M_{i 2} \cdot S_{2}+M_{i 3} \cdot S_{3}=S_{i} \\
M_{i 1} \cdot \Theta_{1}+M_{i 2} \cdot \Theta_{2}+M_{i 3} \cdot \Theta_{3}=\Theta_{i}
\end{array}
$$

where $S_{1}, S_{2}, S_{3}$ and $\Theta_{1}, \Theta_{2}, \Theta_{3}$ are the values of salinity and temperature of each water type (Tomczak, 1981b). Given that three mixing triangles with five water types have been proposed, the proportions of any point present in any of the three triangles can be obtained by applying the system of equations given above for each triangle. Generally, from the resolution of the three mixing triangles, for each data point in Figure 3, the five proportions $\left(M_{i 1}, M_{i 2}, M_{i 3}, M_{i 4}\right.$ and $\left.M_{i 5}\right)$ are determined, considering that at least two values of them are null and void depending on the triangle where each sample is located.

For each additional conservative parameter $(C)$ we obtain:

$$
M_{i 1} \cdot C_{1}+M_{i 2} \cdot C_{2}+M_{i 3} \cdot C_{3}+M_{i 4} \cdot C_{4}+M_{i 5} \cdot C_{5}=C_{i} \cdot
$$

Given that the proportions $\left(M_{i 1}, M_{i 2}, M_{i 3}, M_{i 4}, M_{i 5}\right)$ and the conservative parameter $\left(C_{i}\right)$ of the 930 data points are available, the fitting of the multilinear equation (2) by least squares is made, obtaining the conservative parameters $\left(C_{1}, C_{2}, C_{3}, C_{4}, C_{5}\right)$ of the five water types considered. This fitting procedure also provides the theoretical values of the conservative parameters and the residuals or anomalies for every sample. The improvement of this mixing model in comparison with that of Tomczak (1981a) is to perform the fitting in a single equation (2).

The nutrients (nitrate, phosphate) and $\Sigma \mathrm{CO}_{2}$ in subsurface waters vary due to the oxidation of organic matter. Thus they do not behave as conservative parameters. A large part of the variability is due to the ROM included in the mixing model because 
normally the ROM is a function of depth, and so it shows an important negative correlation with temperature. Furthermore, from the oceanographic point of view, the scale of the working area is not large enough to expect great latitudinal differences in the ROM. Thus, as a first approach, we assume that nutrients, $\Sigma \mathrm{CO}_{2}$ and oxygen behave as conservative parameters on our spatial scale.

The composite parameters "NO," "PO" (Broecker, 1974) and "CAO" (Ríos et al., 1989) have also been used in this model of analysis of water masses. These parameters have the property of not being affected by the oxidation of organic matter. So they are conservative with regard to the biological activity and independent of the water aging. The remineralization processes can be quantified through the stoichiometric ratios $-\triangle \mathrm{O}_{2}: \triangle \mathrm{CO}_{2}: \triangle \mathrm{NO}_{3}: \triangle \mathrm{P}=138: 106: 16: 1$ (Redfield et al., 1963). Takahashi et al. (1985) carried out a review on the 27.0 and 27.2 isopycnal levels of the stoichiometric ratios given by Redfield et al. (1963). The ENAW ${ }_{t}$ and ENAW $_{\mathrm{p}}$ are located along these isopycnal levels. Takahashi et al. (1985) obtained for the North Atlantic the $-\triangle \mathrm{O}_{2}: \triangle \mathrm{CO}_{2}: \triangle \mathrm{NO}_{3}: \triangle \mathrm{P}$ ratios of 165:112:17.6:1. Minster and Boulahdid (1987) critically examined the isopycnal analysis. They found a slightly different ratio $\left(-\triangle \mathrm{O}_{2}: \triangle \mathrm{NO}_{3}: \triangle \mathrm{P}=161: 17.1: 1\right)$. Recently, Ríos et al. (1989) obtained from the elemental composition of marine phytoplankton the following stoichiometric equation:

$\left[\mathrm{C}_{129} \mathrm{H}_{234} \mathrm{O}_{70} \mathrm{~N}_{17} \mathrm{P}\right]+175 \mathrm{O}_{2}+148 \mathrm{OH}^{-} \rightarrow 129 \mathrm{HCO}_{3}^{-}+17 \mathrm{NO}_{3}+\mathrm{HPO}_{4}+126 \mathrm{H}_{2} \mathrm{O}$

with stoichiometic ratios very close to those obtained by Takahashi et al. (1985). Following the definition of the "NO" parameter (Broecker, 1974) and accepting the nomenclature of Minster and Boulahdid (1987), we can define:

$$
\begin{aligned}
\text { "NO" }=\mathrm{O}_{2}+\mathrm{R}_{\mathrm{N}} \cdot \mathrm{NO}_{3}{ }^{-} & ; \mathrm{R}_{\mathrm{N}}=-\triangle \mathrm{O}_{2} / \triangle \mathrm{NO}_{3} \\
\text { "PO" }=\mathrm{O}_{2}+\mathrm{R}_{\mathrm{P}} \cdot \mathrm{HPO}_{4}= & ; \mathrm{R}_{\mathrm{P}}=-\triangle \mathrm{O}_{2} / \triangle \mathrm{HPO}_{4}= \\
" \mathrm{CAO} "=\mathrm{O}_{2}+\mathrm{R}_{\mathrm{C}} \cdot\left(\Sigma \mathrm{CO}_{2}-\left(\mathrm{A}_{\mathrm{t}}+\mathrm{NO}_{3}{ }^{-}\right) / 2\right) & ; \mathrm{R}_{\mathrm{C}}=-\triangle \mathrm{O}_{2} / \triangle \mathrm{CO}_{2}
\end{aligned}
$$

where all the concentrations are expressed in $\mu \mathrm{mol} / \mathrm{kg}$ of seawater which is independent of the pressure and temperature conditions. The inorganic carbon $\left(\Sigma \mathrm{CO}_{2}\right)$ is obtained from total alkalinity $\left(\mathrm{A}_{\mathrm{t}}\right)$ and $\mathrm{pH}$ using the methods described by Pérez and Fraga $(1987 \mathrm{a}, \mathrm{b})$. The term $\mathrm{A}_{\mathrm{t}}+\mathrm{NO}_{3}{ }^{-}$corrects the variations of total inorganic carbon due to the processes of precipitation and re-solution of $\mathrm{CaCO}_{3}$, so that the "CAO" parameter is not affected by these processes (Takahashi et al., 1985; Ríos et al., 1989).

The values of $R_{N}, R_{P}$ and $R_{C}$ were obtained by linear regression of the $\mathrm{NO}_{3}$, $\Sigma \mathrm{CO}_{2}$ and $\mathrm{HPO}_{4}{ }^{=}$anomalies obtained from the mixing model, giving:

$$
\begin{gathered}
\text { "NO" }=\mathrm{O}_{2}+10 \mathrm{NO}_{3}{ }^{-} \\
" \mathrm{PO} "=\mathrm{O}_{2}+163 \mathrm{HPO}_{4}= \\
" \mathrm{CAO} "=\mathrm{O}_{2}+1.32\left(\Sigma \mathrm{CO}_{2}-\left(\mathrm{A}_{\mathrm{t}}+\mathrm{NO}_{3}{ }^{-}\right) / 2\right) .
\end{gathered}
$$


The $R_{N}, R_{P}$ and $R_{C}$ ratios are not significantly different from those that can be obtained from the stoichiometric ratios given by Takahashi et al. (1985), Minster and Boulahdid (1987) and Ríos et al. (1989). These ratios minimize the standard error of the fit of the "NO," "PO" and "CAO" parameters, being independent of remineralization processes. As we shall see later, the variability of nutrients and oxygen anomalies is small. Therefore, the accuracy of $R_{N}, R_{P}$ and $R_{C}$ ratios is not very significant for the real fitting of the "NO," "PO" and "CAO" parameters. But even so, the magnitudes of Broecker's parameters vary when the $R_{N}, R_{P}$ and $R_{C}$ ratios change in expressions (3) to (5). This fact should be taken into account when results of other authors are compared.

The preformed nutrients studied here, that is the nutrients present during the formation of water masses, can be calculated from Broecker's parameters and vice versa using the equations:

$$
\begin{aligned}
\mathrm{NO}_{3}^{\circ} & =\left(" \mathrm{NO} "-\mathrm{O}_{2 \text { sat }}\right) / 10 \\
\mathrm{PO}_{4}^{\circ} & =\left(\text { ("PO" }-\mathrm{O}_{2 \text { sat }}\right) / 163
\end{aligned}
$$

assuming that the new water masses formed during winter mixing reach oxygen saturation. Thus, it is possible to distinguish between the nutrients or $\Sigma \mathrm{CO}_{2}$ generated by remineralization and those already present when the water masses form.

Silicon is not to be expected to show a close stoichiometric relationship with the other nutrient elements and oxygen consumption because the proportions of diatoms in phytoplankton and their degree of silicification vary considerably. However, various authors (Spencer, 1975) reported ratios of $\triangle \mathrm{Si}: \triangle \mathrm{N}$ between 0.5 to 1.2, which implies a ratio $R_{\mathrm{Si}}=-\triangle \mathrm{O}_{2}: \triangle \mathrm{H}_{4} \mathrm{SiO}_{4}$ from 9 to 20 . The ratio $\mathrm{R}_{\mathrm{Si}}=15$ used here, correctly adjusts the deviations which exist in water where a significant ROM is present, and so is sufficiently valid for bodies of water situated above 1000 meters. Thus, the parameter can be defined as

$$
\text { "SiO" }=\mathrm{O}_{2}+15 \mathrm{H}_{4} \mathrm{SiO}_{4}
$$

which has a mean value only for upper waters where it shows conservative behavior. In deep waters where the rate of ROM is low and where an important re-solution of silicon of biogenic origin may take place, the ratio $R_{\mathrm{Si}}=15$ is too high. To estimate the ratio $\mathrm{R}_{\mathrm{Si}}$ in these waters, the ratio Si:N present in the water type is considered.

\section{Results and discussion}

a. Nutrient types. In Table 1 the values of ten chemical parameters for the five water types, expressed in $\mu \mathrm{mol} / \mathrm{kg}$ of seawater, are shown. From these results it is possible to calculate, for a water body defined by salinity and temperature, any of the different 
Table 2. Ratios between nutrient types and those preformed $\left(^{\circ}\right)$ estimated at oxygen saturation, in the five water types studied.

\begin{tabular}{lccccccr}
\multicolumn{1}{c}{ Type } & $\mathrm{O}_{2}{ }^{\circ}$ & $\mathrm{N} / \mathrm{P}$ & $\mathrm{Si} / \mathrm{N}$ & $\mathrm{SiO}_{2}{ }^{\circ}$ & $\mathrm{NO}_{3}{ }^{\circ}$ & $\mathrm{PO}_{4}{ }^{\circ}$ & $\mathrm{N}^{\circ} / \mathrm{P}^{\circ}$ \\
ENAW $_{\mathrm{t}}$ & 254 & 17.5 & 0.29 & 0.3 & 3.5 & 0.19 & 18.4 \\
ENAW $_{\mathrm{p}}$ & 279 & 16.5 & 0.44 & 2.8 & 10.4 & 0.63 & 17.4 \\
$\mathrm{MW}$ & 263 & 17.0 & 0.69 & 3.9 & 5.3 & 0.29 & 18.3 \\
LW & 322 & 14.8 & 0.79 & 4.5 & 12.1 & 0.85 & 14.2 \\
N $A D W$ & 330 & 15.1 & 1.77 & 32.1 & 12.9 & 0.91 & 14.2
\end{tabular}

chemical parameters considered, applying the system of Eqs (1) and (2) with standard deviations given in Table 1.

The model fits the experimental data well if we consider the high correlation coefficients, some fitting the composite parameters ("NO," "PO," "CAO" and "SiO") better than nutrients and oxygen independently, as was to be expected. All composite parameters show standard deviations between $44 \%$ and $60 \%$ lower than those obtained from the linear sum of standard deviations of oxygen and nutrients or $\Sigma \mathrm{CO}_{2}$. Therefore, the most important variations of nutrients are defined by the physical mixing process. The small variations due to the differential remineralization is corrected by Broecker's parameters.

The lowest variance adjusted by the model $\left(r^{2}=0.86\right.$, Table 1$)$ corresponds to the dissolved oxygen. However, the standard deviation of residuals of oxygen is very similar to those given for the composite parameters of Broecker.

The nutrient values obtained for the shallowest water type, $\mathrm{ENAW}_{\mathrm{t}}$, are very low, or even zero in the case of $\mathrm{SiO}_{4} \mathrm{H}_{4}$, and the oxygen values are very close to saturation, taking into account that the types' value are slightly extrapolated, and that important quantities of remineralized nutrients exist in the subsurface layer. The real values, as we shall see later, show anomalies in relation to the model with an increase of nutrient concentration and a decrease of dissolved oxygen concentrations. Considering the variability of the "NO" parameter for the waters of the main thermocline, Broecker (1974) gives a value of "NO" $=290$ at $14^{\circ} \mathrm{C}$ which is very close to that obtained here for the ENAW type (Table 1).

The N:P ratios for the rest of the water types given in Table 2 are similar to the values given by several authors (Takahashi et al., 1985; Minster and Boulahdid, 1987; Ríos et al., 1989). These ratios cause the values of "NO" and "PO" to be similar for the same water body. So, in a water mass, the elemental composition of organic matter determines the ratios between biogenic elements, both in their preformed component and in that regenerated by oxidation. The same table shows the values of preformed nutrients estimated considering that during the formation of new water bodies, the oxygen saturation is 100\% (Spencer, 1975). The high preformed N:P ratio obtained for MW agrees with the high ratios published for the Mediterranean Sea. In the same way, the low N:P ratio obtained for NADW is similar to N:P ratios obtained 
for regions farther south (Le Jehan and Tréguer, 1985). These water include water of Antarctic origin, as the high content of silicate shows (Table 1).

The Si:N ratios in water types (Table 2) incrcase with the depth of origin of cach

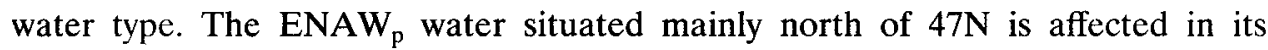
formation by continental waters poor in silicate (Tréguer et al., 1979). The Si:N ratio for LW is similar to those obtained by Clark and Coote (1988) in the Labrador Sea $(\mathrm{Si} / \mathrm{N}=0.76)$ during the formation of new Labrador Water.

Considering the model described by Broecker and Takahashi (1980), and taking into account the values of $\mathrm{H}_{4} \mathrm{SiO}_{4}$ for NADW, this water would have $21 \%$ of water of Antarctic origin (AABW). The Si:N ratio for NADW is higher and close to the range found in Antarctic water (Le Jehan and Tréguer, 1985). So, assuming the same $R_{N}$ ratio, the $\mathrm{R}_{\mathrm{Si}}=6$ ratio is obtained from which the values of "SiO" for NADW are calculated. This change in the ratio does not affect the quality of the fitting due to the slow ROM in deep waters. Using this last ratio for $\mathrm{LW}$, a "SiO" value of $366 \mu \mathrm{mol} / \mathrm{kg}$ is obtained.

b. Distribution of anomalies in ENAW and $M W$. The deviations between the nutrient values observed and those estimated from the model (nutrient anomalies) can be classified in two situations:

1) The nutrients and $\Sigma \mathrm{CO}_{2}$ anomalies have their corresponding and opposite oxygen anomalies in such a way that the "NO," "PO," "SiO" and "CAO" anomalies are close to zero. These anomalies are mainly due to the ROM (it has no influence on Broecker's parameters), and denote water bodies which have a longer residence time in the study area compared with those which show negative oxygen anomalies (positive nutrient anomalies). The water bodies with positive oxygen anomalies indicate the relatively recent presence of the water type in the study area or the existence of ventilation areas.

2) On the contrary, nutrient and/or oxygen anomalies which persist in the distribution of Broecker's parameters, indicate the existence of water bodies of different origin which have not been taken into account in the model.

With the object of identifying the regions or zones of remineralization, the distribution of the anomalies due to fitting the mixing model in the subsurface layers was studied. For this, a section from $40 \mathrm{~N}$ to $47 \mathrm{~N}$ was taken, and all the anomalies averaged from stations at the same latitude (Fig. 1) and during: Galicia-V (November82), Galicia-VI (December-83) and Galicia-VII (February-84) which show a very similar geographical distribution. Although seasonal and also transverse variations exist, they are less important than latitudinal variations which, in their turn, are of a more persistent character.

Figure 4 shows the isopycnal distribution of the water types from $40 \mathrm{~N}$ and $47 \mathrm{~N}$. In the near surface region in the south, ENAW $\mathrm{E}_{\mathrm{t}}$ is dominant whereas the maxima of 


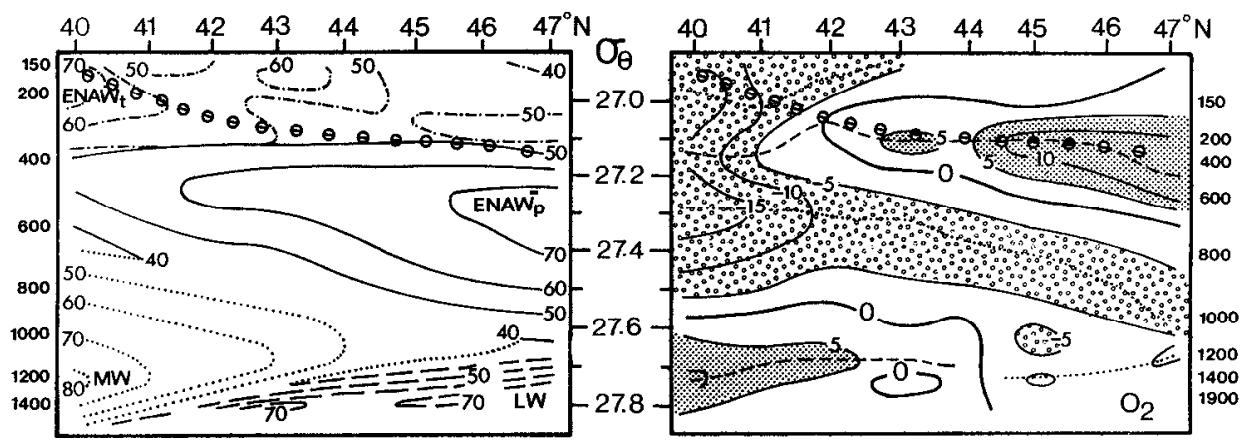

Figure 4. Meridional distribution of percentages of water types identified in Figure 3 and the anomaly of dissolved oxygen in $\mu \mathrm{mol} / \mathrm{Kg}$. The $\Theta$ symbols show the bottom of the surface layer. Maximum and minimum are indicated by dashed and dotted lines, respectively. The closed-dotted areas represent the positive anomalies and open-dotted areas represent negative anomalies.

ENAW $_{\mathrm{p}}$ are situated to the north in the 27.3 isopycnal, and correspond clearly to the formation by winter mixing of great volumes of subpolar mode water to the north of the area (Harvey, 1982). The MW and LW are situated at greater density values, and the maximum of MW shows a rapid decrease near Cape Finisterre (44N). According to the isopycnals, LW is located above MW. This isopycnal deepens below 1000 meters due to the calculation of sigma- $\Theta$ made at zero pressure. This effect disappears if sigma- $\Theta$ is calculated at the 1000 dbar level (Table 1).

The average oxygen anomalies (Fig. 4) are clearly grouped, characterized by negative oxygen anomalies (real values less than calculated by the model) below the ENAW $_{\mathrm{p}}$ maximum, basically along the mixing layer with $\mathrm{MW}$, and in small amounts, in the mixing layer between MW and LW. On the other hand, the positive anomalies of $\mathrm{O}_{2}$ are situated in the MW maxima at $40 \mathrm{~N}$ and in the upper part of the ENAW $47 \mathrm{~N}$. In areas where the influence of $\mathrm{LW}$ is greater, the oxygen anomalies are practically zero. The negative anomaly suggests the presence of a layer where the ROM is maximum, probably due to a greater residence time of these mixing layers in the working area. This implies that these layers are displaced slowly. At the same time the advance and dilution of ENAW $\mathrm{p}_{\mathrm{p}}$ and $\mathrm{MW}$ is associated with an aging that diminishes the oxygen concentration. In the southern part where $\mathrm{ENAW}_{\mathrm{t}}$ prevails, the oxygen anomalies are negative in contrast to the ENAW $_{\mathrm{p}}$. This fact supports the different origins of these two water masses.

Although Maillard (1986) describes the weak displacement of central waters in the direction west-east, other authors (Pollard and $\mathrm{Pu}, 1985$ ) describe and estimate the displacement of ENAW between 27.1 and 27.3 isopycnals from $45 \mathrm{~N}$ toward the south, below a saline wedge that we call here ENAW ${ }_{\mathrm{t}}$. This behavior agrees with the anomalous distribution of oxygen studied here. The maximum oxygen anomaly is observed at $47 \mathrm{~N}$ and spreads below the $\mathrm{ENAW}_{\mathrm{t}}$, close to the 27.15 isopycnal. During 
its advance, the oxygen concentrations of ENAW $_{\mathrm{p}}$ decrease by $0.56 \mathrm{ml} / \mathrm{l}$ $(25 \mu \mathrm{mol} / \mathrm{kg}$ ) from 47 to $40 \mathrm{~N}$. This value is slightly higher than that of Pollard and $\mathrm{Pu}$ (1985) from 45 to $40 \mathrm{~N}$. Considering an oxygen consumption rate of $0.15 \mathrm{ml} \mathrm{l}^{-1} \mathrm{y}^{-1}$ obtained by the same authors, a ventilation time of the order of four years has been estimated from 47 to $40 \mathrm{~N}$. This is, an advection rate of $0.6 \mathrm{cms}^{-1}$, similar to that obtained by the former authors. Packard et al. (1988a) gave data of oxygen utilization rate (OUR) obtained from the ETS activity in the North Western Sargasso Sea between $0.056 \mathrm{ml} \mathrm{O}_{2} 1^{-1} \mathrm{y}^{-1}$ and $0.27 \mathrm{ml} \mathrm{O}_{2} \mathrm{I}^{-1} \mathrm{y}^{-1}$. They also gave higher values in the North Central Pacific Ocean close to $0.27 \mathrm{ml} \mathrm{O}_{2} 1^{-1} \mathrm{y}^{-1}$ between 200 and $400 \mathrm{~m}$.

The variability of the nutrients and oxygen in the ENAW $_{\mathrm{p}}$ and $\mathrm{ENAW}_{\mathrm{t}}$ are not predicted by the mixing model in a single equation. These two water masses differ in that they show opposite anomalies of oxygen. On the other hand, their values of "NO," "PO," "CAO" and "SiO" are adjustable linearly for these water bodies, even farther to the south. As we will see later on, the "NO" values recorded in Sines (38N) by GROUPE MEDIPROD (1983) are quite similar to those estimated here. All this indicates a differential oxidation and/or a different ventilation rates between ENAW and $\mathrm{ENAW}_{\mathrm{p}}$. So, although low values of nutrients are expected in $\mathrm{ENAW}_{\mathrm{t}}$ due to its higher temperature (Table 1), its greater degree of oxidation causes an increase of nutrient levels and a decrease of oxygen concentrations (Figs. 4 to 6). We can affirm just the contrary for the $\mathrm{ENAW}_{\mathrm{p}}$. The nutrient distribution described by Tréguer $e t$ al. (1979) in the Bay of Biscay shows similar behavior.

To compare the different levels in the nutrient anomalies obtained by the model, they have been multiplied by the corresponding stoichiometric coefficients (Eqs. 3 to 5). The anomaly distributions for nitrate, total inorganic carbon, phosphate and silicate are shown in Figures 4 and 5, expressed in equivalent units of . oxygen $(\mu \mathrm{mol} / \mathrm{kg})$. All distributions show a concordant behavior, but with the opposite sign of the distribution of oxygen anomalies, in such a way that the "NO," "PO," "CAO" and "SiO" anomalies are slightly significant, which is expected when the nutrient anomalies are due only to ROM. Broecker's parameters are similarly shown with their corresponding nutrients in the same figures, and in general reveal a random distributions. The silicate distribution shows the lowest values of the anomalies and weaker gradients along the mixing zone between MW and ENAW. On the other hand, the nitrate anomaly distribution is somewhat greater and with stronger gradients. In general, the nutrient anomalies show negative values associated with the water type (except ENAW $)_{1}$ ), and positive values associated with the mixing zones.

The northward increase of nutrient anomalies (the opposite for $\mathrm{O}_{2}$ ) in the MW maximum indicates a differential remineralization in the direction of advance, approximately equivalent to $0.45 \mathrm{ml} / 1(\approx 20 \mu \mathrm{mol} / \mathrm{kg})$ of oxygen, from 40 to $47 \mathrm{~N}$. Although Madelain (1967) recorded speeds of $10 \mathrm{~cm} \mathrm{~s}^{-1}$, the mean values estimated for the MW tongue between 800 to $1200 \mathrm{~m}$ and situated between the Iberian 
Peninsula and $11 \mathrm{~W}$, are of the order of $1.5 \mathrm{~cm} \mathrm{~s}^{-1}$, which leads to an oxygen consumption rate close to $0.3 \mathrm{ml} \mathrm{l}^{-1} \mathrm{y}^{-1}$, which is higher than that estimated by Pollard and Pu (1985) (0.05-0.15 $\mathrm{ml} \mathrm{l}^{-1} \mathrm{y}^{-1}$ at $500 \mathrm{~m}$ ) and that given by Kester (1975) of $0.035 \mathrm{ml} \mathrm{l}^{-1} \mathrm{y}^{-1}$ at a mean depth of $700 \mathrm{~m}$ for the Atlantic Ocean. This important difference could be due to the following. Although the tongue of $\mathrm{MW}$ is located at greater depth, an increase in oxygen consumption can be caused by an increase in the flux of particulate matter by the relatively high temperature of the water mass, by its proximity to the slope of the Iberian Peninsula, and by its proximity to an area of high primary production due to coastal upwelling. The aging of the MW which increases in the direction of the current, emphasizes the oxygen minimum, allowing an easier detection of MW even when it is present in small proportions. Packard et al. (1988b) described the formation of the Alboran oxygen minimum zone, finding values of OUR up to $0.20 \mathrm{ml} \mathrm{l}^{-1} \mathrm{y}^{-1}$

The opposite displacement of ENAW water masses a region of relatively stagnant water where the differential remineralization rates (Fig. 4) are high. The maximum negative oxygen anomaly is situated close to the isoline of $60 \%$ of $\mathrm{ENAW}_{\mathrm{p}}$ and $30 \%$ of $\mathrm{MW}$. The maxima of positive nutrient anomalies are similarly situated (Figs. 5 and 6 ). As an example of this, the $\Theta-S$ diagram (Fig. 7a) from a station close to Cape Finisterre shows that in the linear mixing between the ENAW $\mathrm{p}_{\mathrm{p}}$ minimum (point $a$ ) and the MW maximum (point $b$ ), an increase of $\mathrm{NO}_{3}(2 \mu \mathrm{mol} / \mathrm{kg}$; Fig. $7 \mathrm{~b})$ and an equivalent decrease of oxygen $(17 \mu \mathrm{mol} / \mathrm{kg})$ in addition to that expected by mixing. Whereas in the "NO"- $S$ diagram these anomalies remain balanced, and show a strong similarity with the $\Theta-S$ profile. So, a layer of relatively low velocity exists in which an increase of nutrients is produced and also the oxygen minimum is emphasized and moved to become associated with the mixing layer at about $100 \mathrm{~m}$ above the salinity maximum.

c. Comparison with data outside the study area. Table 3 summarizes the hydrographic and nutrients data of 10 different stations of ENAW, MW, LW and NADW in the vicinity of Cape Finisterre. For comparison, as well as to test out the model, we have calculated the phosphate, nitrate, silicate and oxygen values for the corresponding stations.

In the area of the Bay of Biscay, Tréguer et al. (1979) define, two types of North Atlantic Central Water, Central North (CN) and Central South (CS), for which they determine the relations between nutrients and salinity. These water bodies correspond respectively to ENAW ${ }_{\mathrm{p}}$ and ENAW . In Table 3, reference 1, the intervals of salinity, temperature and nutrients are given for CS water which penetrates from the south of the Bay of Biscay. The nutrients estimated from our model for this same water are close to their values. In the same table, reference 2, the data corresponding to $\mathrm{CN}$ water which penetrates the Bay of Biscay from the north, are also given. The anomalies obtained by the model are similar among the different nutrients. In 


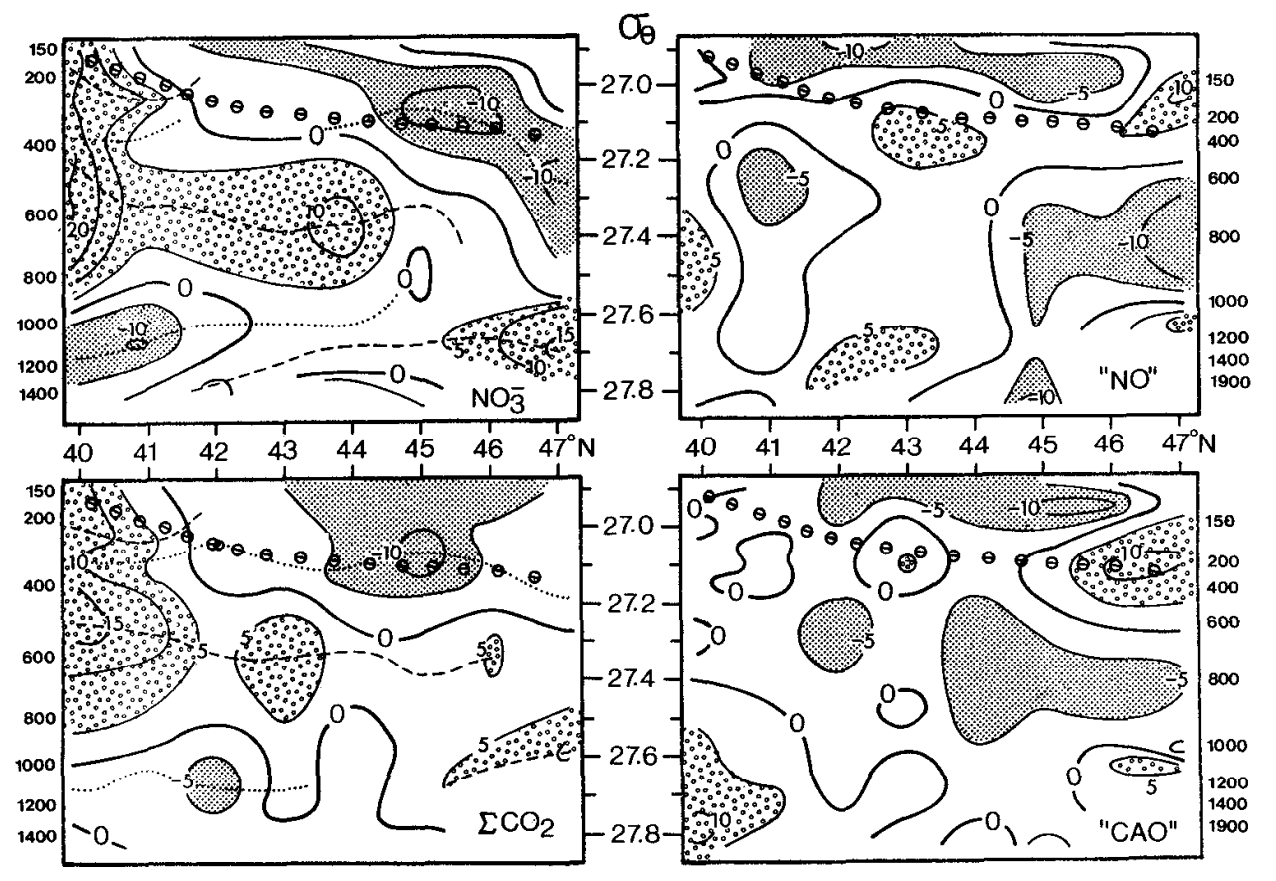

Figure 5. Meridional distribution of nitrate, "NO," total inorganic carbon and "CO" anomalies, expressed in units of oxygen $(\mu \mathrm{mol} / \mathrm{Kg})$, taking into account the stoichiometric ratios. The $\Theta$ symbols show the bottom of the surface layer. Maximum and minimum are indicated by dashed and dotted lines, respectively. The closed-dotted areas represent negative anomalies and open-dotted areas represent positive anomalies.

addition, the negative anomalies are concordant with those shown in the north (about $47 \mathrm{~N}$ ) of our working area (Figs. 5 and 6). This also agrees with the fact that ENAW $_{\mathrm{p}}$, more ventilated, is located to the north of $47 \mathrm{~N}$. Unfortunately, Tréguer $e t$ al. (1979) do not give at the simultaneous oxygen data for this area which could show the formation and greater ventilation of $\mathrm{CN}$ water defined by them.

To the south of our working area (Cape Sines, $38 \mathrm{~N}, 9 \mathrm{~W}$ ), the GROUPE MEDIPROD (1983) carried out measurements of nutrients and oxygen during the RCA-1 cruise, that we have subjected to a similar model to the one shown here and from which we have obtained the values for the first three water types used here. The anomalies of nutrient (reference 3 of Tables 3 and 4) calculatcd for the ENAW agree with the oxygen anomaly, and indicate a great remineralization of this water type to the south of the working area, which coincides with the data shown in Figures 4 to 6 . The differences obtained for the different nutrients, off Sines for the $\mathrm{ENAW}_{\mathrm{p}}$ are not coherent among themselves, and give rise to important differences in the "SiO" and "NO" values. This is probably due to the fact that there, the proportions of $\mathrm{ENAW}_{\mathrm{p}}$ are very low and a significant extrapolation of the calculated 


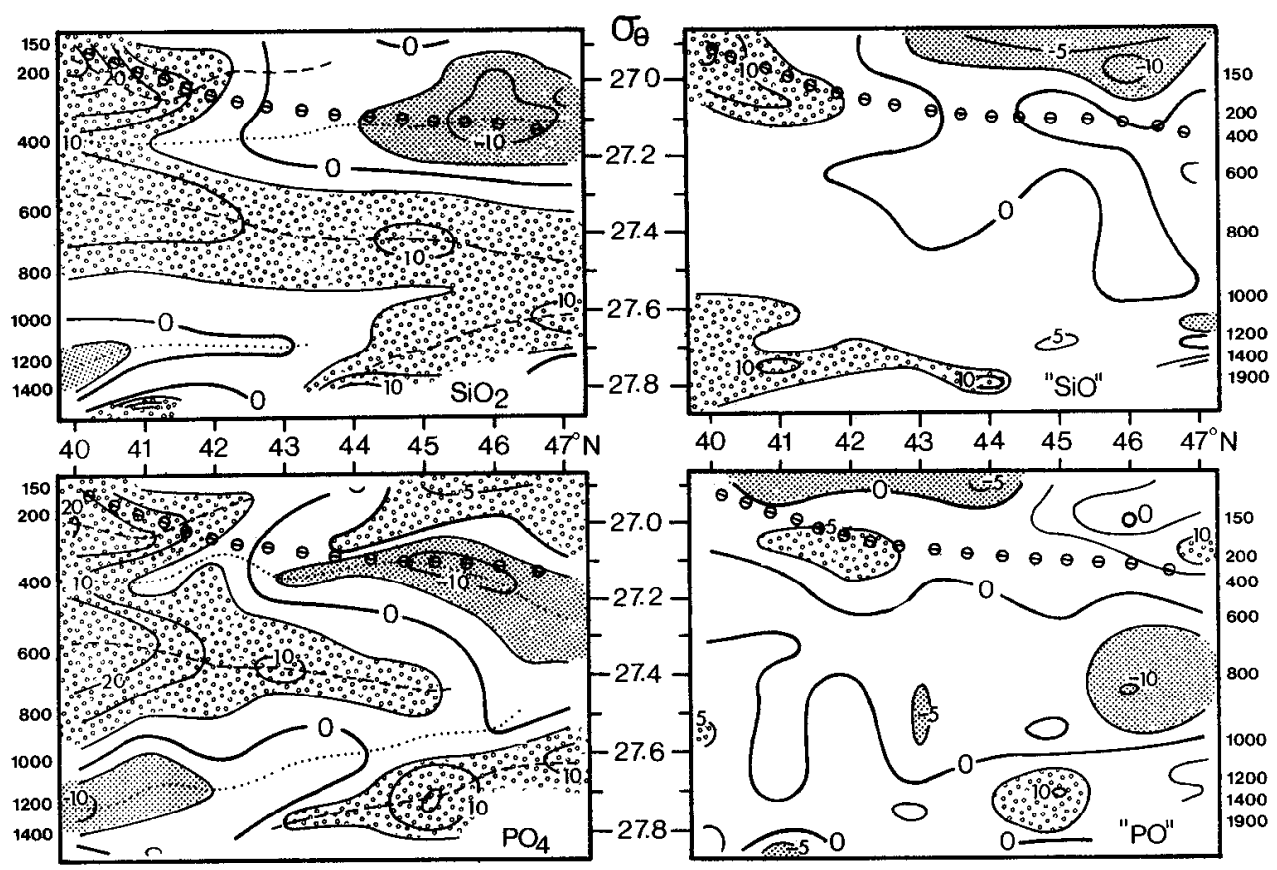

Figure 6. Meridional distribution of phosphate, "PO," silicate and "SiO" anomalies, expressed in units of oxygen $(\mu \mathrm{mol} / \mathrm{Kg})$, taking into account the stoichoimetric ratios. The $\Theta$ symbols show the bottom of surface layer. Maximum and minimum are indicated by dashed and dotted lines, respectively. The closed-dotted areas represent negative anomalies and open-dotted areas represent positive anomalies.

values must be carried out. Besides, the influence of shallower tongues of MW (Ambar, 1983) can introduce significant anomalies if they have not been taken into account.

Farther to the south, in the Bay of Cadiz, Le Corre and Tréguer (1976) show values of salinity, temperature, nutrients and oxygen for ENAW (Table 3). The values of estimated nutrients using our model show positive anomalies, similar and opposite in sign to those of oxygen. For this reason, "NO," "PO" and "SiO" values (Table 4) are relatively close to zero, and again indicating the greater degree of oxidation in ENAW situated farther to the south of our working area.

Nutrient values are also shown in Table 3 for the MW present between the formation zone (Bay of Cadiz, reference 4) and our study area. The agreement between the different anomalies is good. In general, the differences are higher in absolute value than those obtained in the southern part $(40 \mathrm{~N})$ of our working area (Figs. 4 to 6) which indicate a lower age of the waters close to the Strait of Gibraltar. Off Sines (reference 3 ) the anomalies are close to those recorded by us at $40 \mathrm{~N}$ (Figs. 4 to 6) and lower than those obtained in the Bay of Cadiz. Although the "NO" 


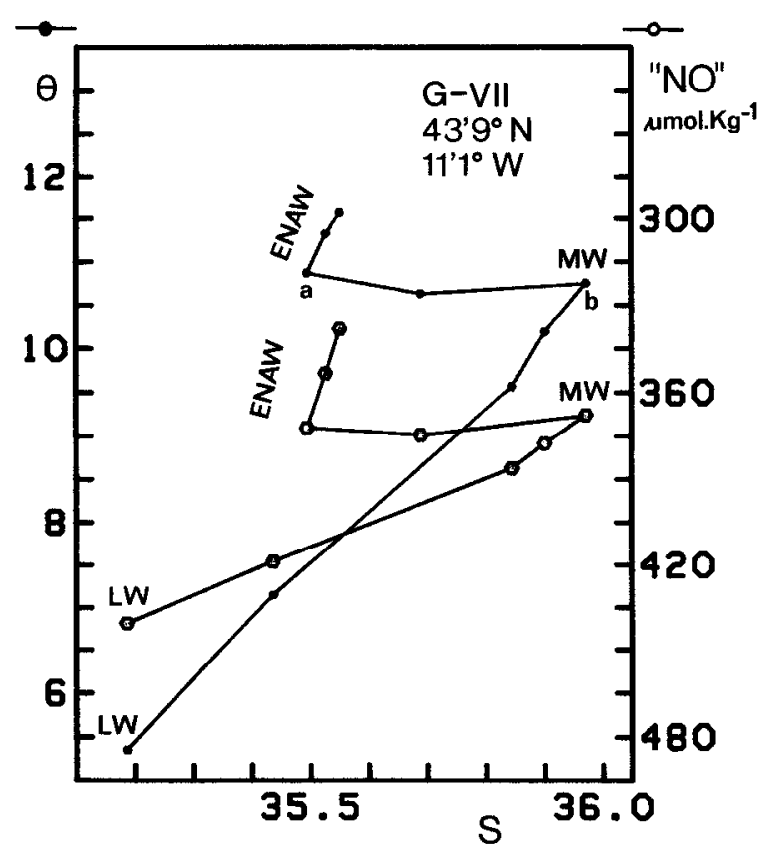

Figure 7a. $\Theta-S$ and "NO"-S diagrams for the data of the station 13 indicated in Fig. 1 (Feb-84, Galicia VII). The mixing between $\mathrm{ENAW}_{\mathrm{p}}$ and $\mathrm{MW}$ is indicated by the line from a to $\mathrm{b}$.

and "SiO" values are significant (Table 4), these are rather lower in absolute value than the nutrient anomalies (Table 3).

Clarke and Coote (1988) studied the formation of the LW, and give nutrient and oxygen values. Their values show concordant anomalies of nitrate and oxygen, and very similar "NO" values (Table 4). Pingree (1973) in the Bay of Biscay (reference 8) gives silicate and oxygen values. These values of silicate are greater than calculated here, but "SiO" is practically the same. These features indicate greater aging in the LW found by Pingree (1973). Broecker and Peng (1982) also give values of nutrients and oxygen for the deep LW whose characteristics are shown in reference (9a) (Table 3). Small negative nitrate, phosphate and silicate anomalies show an aged LW in our study area, although significant "NO" differences exist. Also, in the Labrador Sea, Anderson et al. (1985) gave average thermohaline characteristics of LW obtained from 18 stations (Table 3, reference 10). These values are close to Broecker and Peng's data, and show good agreement with Broecker's parameters except for "NO" (Table 4). With an oxygen utilization rate of $9 \mu \mathrm{O}_{2} \mathrm{l}^{-1} \mathrm{y}^{-1}\left(0.4 \mu \mathrm{mol} \mathrm{kg}^{-1} \mathrm{y}^{-1}\right)$ given by Packard et al. (1988a) at $2000 \mathrm{~m}$, close to maximum LW level, the LW would take about seventy five years to reach the western coast of the Iberian Peninsula from its formation area, that is to say, the $\mathrm{LW}$ advances at a mean speed of the order of $0.2 \mathrm{~cm} / \mathrm{s}$. 


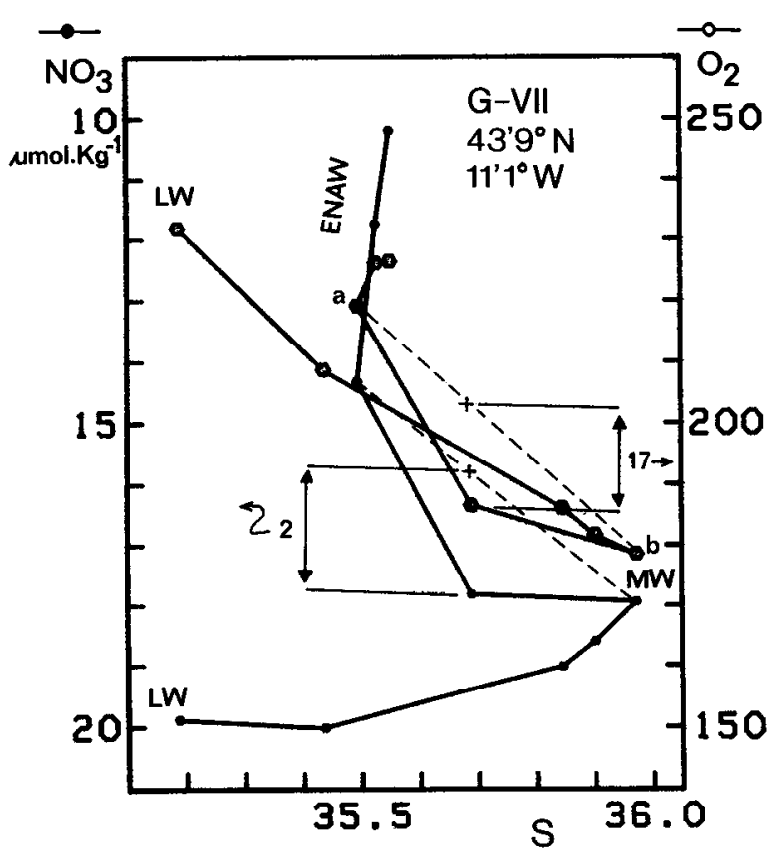

Figure $7 \mathrm{~b} . \mathrm{NO}_{3}-\mathrm{S}$ and $\mathrm{O}_{2}-\mathrm{S}$ diagrams for the data of the station indicated in Figure 1 (Feb-84, Galicia $V I I)$. The estimated regeneration rates of nutrients have been made considering the linear mixing.

In our nutrient analysis, there are only 36 points situated in the deepest mixing triangle, in which samples of water below the oxygen maximum layer of LW were obtained. It can be seen in Tables 3 and 4 that the nutrient values for the NADW show small differences with regard to the values obtained by Broecker and Takahashi (1980) for the nearest GEOSECS stations. The differences in "NO" and "SiO" are low if we compare them with those values obtained to the south of our area where waters of Antarctic origin have more influence. Also the values of NADW obtained here for $\mathrm{SiO}_{2}$ and "NO" agree with the $\mathrm{SiO}_{2^{-}}$"NO" ratios for the mixing of NADW and AABW given by Broecker and Takahashi (1980) in the eastern basin of the North Atlantic.

\section{Conclusions}

Using the mixing triangle analysis, the thermohaline variability is removed from the nutrients, oxygen and $\Sigma \mathrm{CO}_{2}$ distribution, and only the variability due to different degrees of remineralization remains. The anomalies of nutrients and oxygen show the existence of two bodies of ENAW with different degrees of ventilation, advancing in opposite directions. A mixing layer between $\mathrm{MW}$ and the $\mathrm{ENAW}_{\mathrm{p}}$ is also shown, in which the remineralization is differentially higher than that corresponding to either 


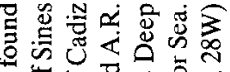

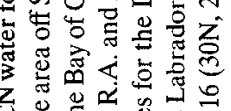

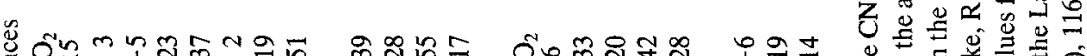

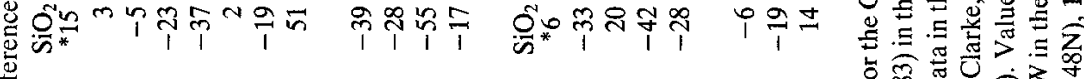
造遂-

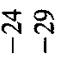

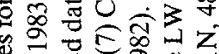

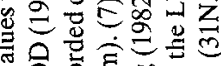

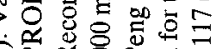

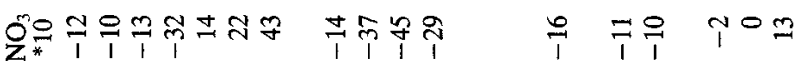

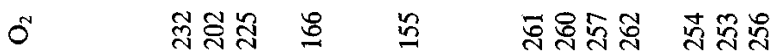

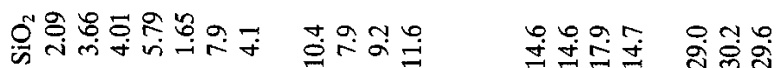

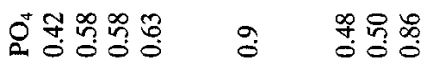

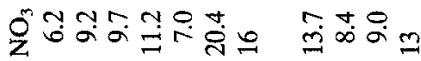

4

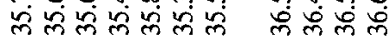

-

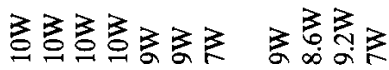

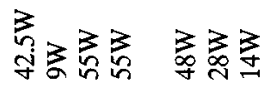

으요.

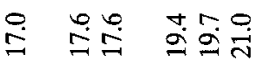

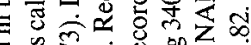

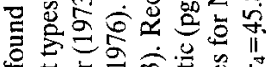
을

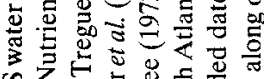

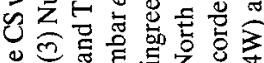

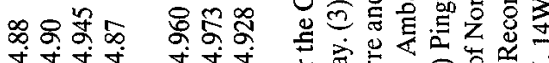

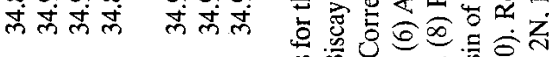

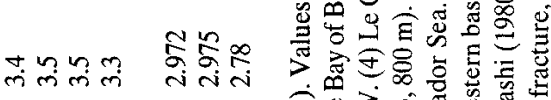

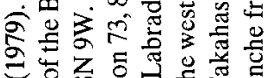

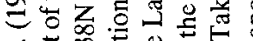

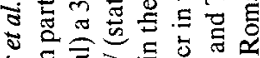

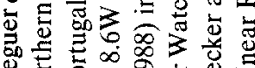

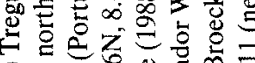

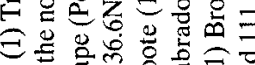

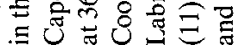


Table 4. Comparison of the Broecker parameters estimated from the model. The references and positions correspond to the previous table.

\begin{tabular}{|c|c|c|c|c|c|c|c|c|c|c|}
\hline \multirow[b]{3}{*}{$\Theta$} & \multicolumn{10}{|c|}{ ENAW } \\
\hline & \multicolumn{4}{|c|}{ Measured } & \multicolumn{3}{|c|}{ Estimated } & \multicolumn{3}{|c|}{ Differences } \\
\hline & $S$ & "NO" & "PO" & "SiO" & "NO" & "PO" & "SiO" & "NO" & "PO" & "SiO" \\
\hline 13.71 & $35.81_{5}$ & 295 & & 253 & 303 & & 266 & 6 & & $-6(3)$ \\
\hline 9.4 & 35.30 & 397 & & 292 & 383 & & 320 & 13 & & $-28(3)$ \\
\hline 11.2 & 35.55 & 351 & 338 & 304 & 342 & 337 & 287 & 9 & 1 & $17(4)$ \\
\hline \multicolumn{11}{|c|}{ Mediterranean Water } \\
\hline 11.7 & 36.5 & 324 & & 304 & 316 & & 321 & 8 & & $-17(3)$ \\
\hline 11.9 & 36.67 & 315 & 325 & 317 & 314 & 308 & 329 & 1 & 17 & $-14(4)$ \\
\hline \multicolumn{11}{|c|}{ Labrador Water } \\
\hline 3.4 & 34.88 & 464 & & 349 & 447 & & 349 & 17 & & $0(7)$ \\
\hline 3.5 & 34.90 & & & 358 & & & 347 & & & $11(8)$ \\
\hline 3.5 & $34.94_{5}$ & 463 & 466 & 353 & 445 & 460 & 365 & 19 & 6 & $-12(9)$ \\
\hline 3.3 & 34.87 & 468 & 466 & 352 & 442 & 461 & 350 & 20 & 1 & $1(10)$ \\
\hline \multicolumn{11}{|c|}{ NADW } \\
\hline $2.97_{2}$ & 34.960 & 454 & & 428 & 450 & & 428 & 4 & & $0(11)$ \\
\hline $2.97_{5}$ & 34.973 & 452 & & 417 & 450 & & 434 & 2 & & $17(11)$ \\
\hline 2.78 & 34.928 & 460 & & 442 & 453 & & 433 & 7 & & $9(11)$ \\
\hline
\end{tabular}

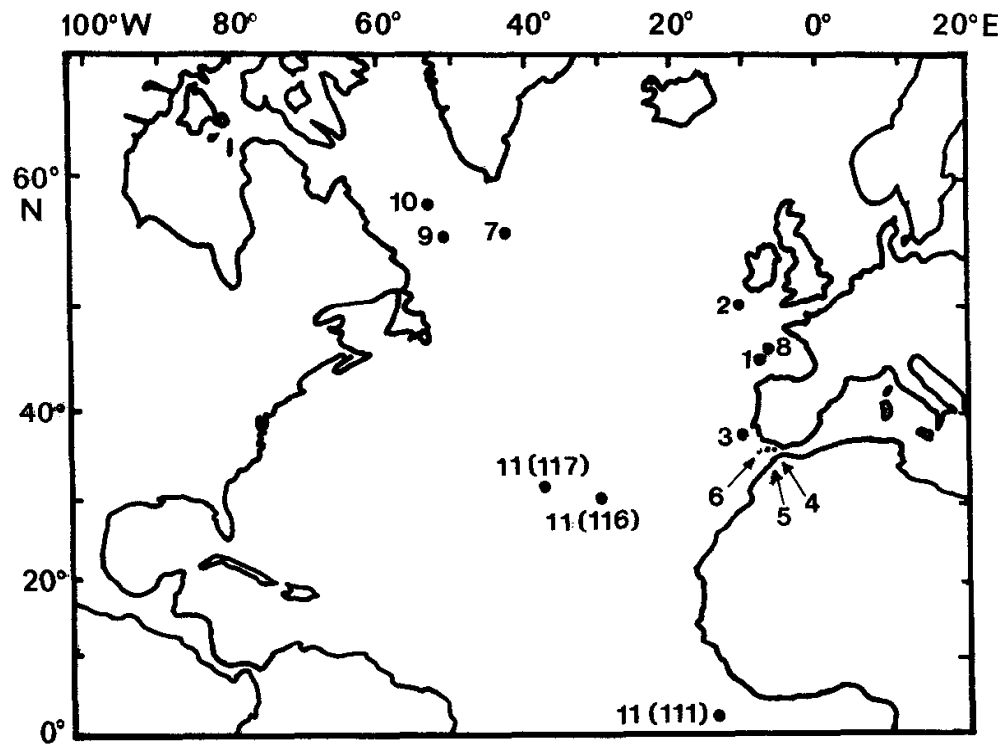

Figure 8. Positions of stations cited in Tables 3 and 4. 
water mass independently. This implies the existence of a layer of very slow displacement situated above MW with a proportion of $60 \%$ of ENAW $_{\mathrm{p}}$.

With regard to the MW, the nutrient values observed show significant remineralization processes along the slope of the Iberian Peninsula, and the its associated oxygen minimum is emphasized.

This analysis facilitates the comparison of this data set with nutrient data obtained in other zones, and Broecker's parameters are used for this purpose. The comparison performed here with different water types shows small variations in relation with the data obtained by other authors, when Broecker's parameters are used. On the other hand, significant differences in oxygen and nutrient concentrations due to aging are shown.

Acknowledgments. This work was supported by the grant number MAR88-245 of the "Comision Interministerial de Ciencia y Tecnología" (CICYT). We thank Ramón Penín and Trinidad Rellán for drawing the figures. We would also like to thank the anonymous reviewers for their valuable suggestions and comments on an earlier version of this paper. The corrections made by Dr. Timothy Wyatt are gratefully acknowledged.

\section{REFERENCES}

Ambar, I. 1983. A shallow core of Mediterranean water off western Portugal. Deep-Sea Res., $30,677-680$.

Ambar, I., M. R. Howe and M. I. Abdullah. 1976. A physical and chemical description of the Mediterranean outflow in the Gulf of Cadiz. Deutsche Hydrographische Zeitschrift, 29, 2, $58-68$.

Anderson, L. G., A. R. Coote and E. P. Jones. 1985. Nutrients and alkalinity in the Labrador Sea. J. Geophys. Res., 90(C4), 7355-7360.

Broecker, W. S. 1974. "NO," A conservative water-mass tracer. Earth Planet. Sci. Lett., 23, 100-107.

Broecker, W. S. and T.-H. Peng. 1982. Tracers in the Sea, Lamont-Doherty Geological Observatory, New York, $690 \mathrm{pp}$.

Broecker, W. S. and T. Takahashi. 1980. Hydrography of the central Atlantic-III. The North Atlantic deep-water complex. Deep-Sea Res., 27A, 591-613.

Clarke, R. A. and A. R. Coote. 1988. The formation of Labrador Sea water. Part III: The evolution of oxygen and nutrient concentration. J. Phys. Oceanogr., 18, 469-80.

Coste, B., A. F. G. Fiuza and H. J. Minas. 1986. Conditions hydrologiques et chimiques associées à l'upwelling côtier du Portugal en fin d'ete. Oceanol. Acta, 9, 149-158.

Fiuza, A. F. G. 1984. Hidrologia e dinamica das aguas costeiras de Portugal, These Doctoral Science, Univiversity. Lisbonne, Portugal 294 pp.

Fraga, F. 1981. Upwelling off the Galician coast, northwest Spain, in Coastal Upwelling, F. A. Richards, ed., American Geophysical Union, Washington, 176-182.

Fraga, F., E. D. Barton and O. Llinás. 1985a. The concentration of nutrient salts in "pure" North and South Atlantic Central Waters. Int. Symp. Upw. W Afr., Inst. Inv. Pesq. Barcelona, $I, 25-36$.

Fraga, F., C. Mouriño and M. Manríquez. 1982. Las masas de agua en la costa de Galicia: junio-octubre. Resultados Expediciones Científicas, 10, 51-77.

Fraga, F., C. Mouriño, F. F. Pérez, A. F. Ríos and C. Marrasé. 1985b. Campaña "Galicia VII." Datos básicos. Datos Informativos Instituto Investigaciones Pesqueras, 12, 1-50. 
Frouin, R., Fiuza, A. F. G., I. Ambar and T. J. Boyd. 1990. Observations of a poleward surface current off the coasts of Portugal and Spain during winter. J. Geophys. Res., 95, 679-91.

Groupe Mediprod. 1983. Remontées d'eaux sur les côtes atlantiques du Portugal-Campagne RCA I (28 août-19 septembre 1981). Publ. CNEXO, Résultats campagnes à la mer, 25, 115 pp.

Harvey, J. 1982. $\Theta-S$ relationship and water masses in the Eastern North Atlantic. Deep-Sea Res., 29, 1021-1033.

Howe, M. R., M. I. Abdullah and S. Deetae. 1974. An interpretation of the double $T-S$ maxima in the Mediterranean outflow using chemical tracers. J. Mar. Res., 32, 377-386.

Käse, R. H., A. Beckmann and H. H. Hinrichsen. 1989. Observational evidence of salt lens formation in the Iberian Basin. J. Geophys. Res., 94, 4905-4912.

Kester, D. R. 1975. Dissolved gases other than $\mathrm{CO}_{2}$. in Chemical Oceanography, J. P. Riley, and G. Skirrow, eds, Academic Press. London, 606 pp.

Lacombe, H. and P. Tchernia. 1960. Quelques traits généraux de l'hydrologie Méditerranéenne. Cahiers Océanographiques, 12, 527-547.

Le Corre, P. and P. Tréguer. 1973. Contribution a l'etude de la matiere organique dissoute et des sels nutritifs dans l'eau de mer. Caracterisitics chimiques du golfe de Gascogne et des upwelling côtiers de l'Afrique du Nord-Ouest. These à L'Université de Bretagne Occidentale, $492 \mathrm{pp}$.

Le Jehan, S. and P. Treguer. 1985. The distribution of inorganic nitrogen, phosphorus, silicon and dissolved organic matter in surface and Deep Water of the Southern Ocean, in Antartic Nutrient Cycles and Food Webs. W. R. Siegfried, P. R. Condy and R. M. Laws, eds., Berlin. 2229.

Madelain, F. 1967. Calculs dynamiques au large de la peninsule Iberique. Cahiers Oceanographiques $X I X, 181-193$.

— 1972. Donnces sur la circulation d'caux d'originc méditcrranćcnne au nivcau du cap Finisterre. Rapport. Scientifique et Technique. CNEXO, 11, $18 \mathrm{pp}$.

Maillard, C. 1986. Atlas Hydroligique de L'Atlantique Nord-Est. Institut Francais de Recherche pour L'Exploitation de la Mer. (IFREMER): 199 pp.

McCartney, M. S. and L. D. Talley. 1982. The subpolar mode water of the North Atlantic Ocean. J. Phys. Oceanogr., 12, 1169-1188.

Minas, H. J., L. A. Codispoti and R. C. Dugdale. 1982. Nutrients and primary production in the upwelling region of Northwest Africa. Rapp. P. v Reun. Cons. Int Explor. Mer., 180, $148-183$.

Minster, J. F. and M. Boulahdid. 1987. Redfield ratios along isopycnal surfaces-a complementary study. Deep-Sea Res., 34, 1981-2003.

Mouriño, C., F. F. Pérez, A. F. Ríos, M. Manríquez and F. Fraga. Campaña "Galicia V." 1985. Datos básicos. Datos Informativos Instituto Investigaciones Pesqueras, 10, $29-61$.

Mouriño, C., F. F. Pérez, A. F. Ríos, M. Manríquez, M. Estrada, C. Marrasé, R. Prego and F. Fraga. 1984. Campaña "Galicia VIII." Datos básicos. Datos Informativos Instituto Investigaciones Pesqueras, 13, 1-108.

Packard, T. T., M. Denis, M. Rodier and P. Garfield. 1988a. Deep-ocean metabolic $\mathrm{CO}_{2}$ production: calculations from ETS activity. Deep-Sea Res., 35, 371-382.

Packard, T. T., H. J. Minas, B. Coste, R. Martinez, M. C. Bonin, J. Gostan, P. Garfield, J. Christensen, Q. Dortch, M. Minas, G. Copin-Montegut and C. Copin-Montegut. 1988b. Formation of the Alboran oxygen minimum zone. Deep-Sea Res., 35, 1111-1118.

Parrilla, G. and J. M. G. Morón. 1971. Conribución al estudio de la vena de agua mediterranea 
en la costa occidental de la Penınsula Iberica. Boletín del Instituto Español de Oceanografia, $145,23 \mathrm{pp}$.

Pérez, F. F. and F. Fraga. 1987a. The pH measurements in seawater on NBS scale. Mar. Chem., 21, 315-327.

$1987 \mathrm{~b}$. A precise and rapid analytical procedure for alkaliniy determination. Mar. Chem., $21,169-182$.

Pérez, F. F., A. F. Ríos, F. F. Fraga and C. Mouriño. 1985. Campaña “Galicia VII.” Datos básicos. Datos Informativos Instituto Investigaciones Pesqueras, 11, 1-38.

Pingree, R. D. 1973. A component of Labrador Sea Water in the Bay of Biscay. Limnol. Oceanogr., 185, 711-718.

Pollard, R. T. and S. Pu. 1985. Structure and ventilation of the upper Atlantic Ocean northeast of the Azores. Progr. Oceanogr., 14, 443-462.

Redfield, A. C., B. H. Ketchum and F. A. Richards. 1963. The influence of organisms on the compositions of sea-water, in The Sea, 2, John Wiley \& Sons, New York, 554 pp.

Ríos, A. F., F. Fraga and F. F. Pérez. 1989. Estimation of coefficients for the calculation of "NO," "PO" and "CO," starting from the elemental composition of natural phytoplankton. Scientia Marina, 53, 779-784.

Ríos, $\Lambda$. F., F. F. Perez and F. Fraga. 1992. Water Masses in upper and middle Atlantic Ocean East of Azores. Deep-Sea Res., 39, 645-658.

Spencer, C. P. 1975. The micronutrient elements, in Chemical Oceanography, J. P. Riley and G. Skirrow, eds., Academic press, London, 245-297.

Sverdrup, H. U., M. W. Johnson and R. H. Fleming. 1942. The Oceans. Their Physics, Chemistry and General Biology. Prentice-Hall, $1087 \mathrm{pp}$.

Takahashi, T., W. S. Broecker and S. Langer. 1985. Redfield ratio based on chemical data from isopycnal surfaces. J. Geophys. Res., 90, 6907-6924.

Talley, L. D. and M. S. McCartney. 1982. Distribution and Circulation of Labrador Sea Water. J. Phys. Oceanogr., 12, 1189-1205.

Tomczak, M. 1981a. A multi-parameter extension of temperature/salinity diagram techniques for the analysis of non-isopycnal mixing. Progr. Oceanogr., 10, 147-171.

Tomczak, M. 1981b. An analysis of mixing in the frontal zone of South and North Atlantic. central water off northwest Africa. Progr. Oceanogr., 10, 173-192.

Tréguer, P., P. Le Corre and J. R. Grall. 1979. The seasonal variations of nutrients in the upper waters of the Bay of Biscay region and their relation to phytoplankton growth. Deep-Sea Res., 26A, 1121-1152.

Worthington, L. V. and W. R. Wright. 1970. North Atlantic Ocean Atlas of potential temperature and salinity in the Deep Water, Including Temperature, Salinity and Oxygen Profiles from the Erika Dan Cruise of 1962. Woods Hole Oceanographic Institution Atlas Series, 2, 58 plates.

Wüst, G. and A. Defant. 1936. Schichtung und Zirculation des atlantischer Ozean Meteor Werk. Deutsche Atlantische Exped. Meteor 1925-1927, Wiss. Erg., Bd. VI, Atlas, 103 pls. Berlin. 